\title{
Cihannüma
}

Tarih ve Coğrafya Araştırmaları Dergisi

Say1 VII/1 - Temmuz 2021, 220-223

Doi: $10.30517 /$ cihannuma.970850

Veliki osječki most: povijesni dossier $i$ suvremena interpretacja $=$ The great Osijek bridge : historical dossier and contemporary interpretation, Ed. Andrija Mutnjaković, Zagreb - Osijek: Croatian Academy of Sciences and Arts, Institute for Scientific and Artistic Work in Osijek, 2014, 165 shf., ISBN: 978-953-154-272-2

"Mursa Aeterna" serisinin ikincisi olarak hazırlanan bu eserde, Hırvatistan'daki Osijek şehrinin Osmanlı dönemi ve bu dönemde inşa edilen Ösek Köprüsü (Cisr-i Ösek) detaylariyla okurlara sunulmuştur. Mursa Aeterna I ve II olarak 2014 yilında yayınlanan eserler, Hirvat Bilim ve Sanat Akademisi'nin Osijek tarihine dair araştırmalarını kapsamaktadır. The great Osijek bridge: historical dossier and contemporary interpretation (Mursa Aeterna II) başliklı kitabın hazırlanmasında Hirvatistan'daki Türkiye Büyükelçiliği ve Türkiye Sualtı Arkeolojisi Enstitüsü (TINA) destek sağlamıştır. Dönemin Hırvatistan

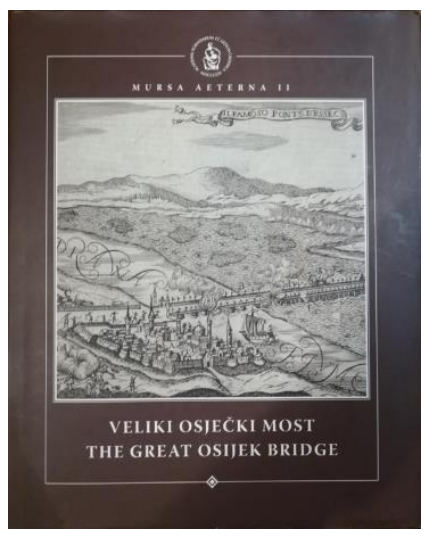
Büyükelçisi Burak Özügergin ve TINA'nın başkanı Oğuz Aydemir’in önsözüyle başlayan eserde giriş ve dört ana bölüm yer almaktadır.

Eser, İngilizce ve Hırvatça olarak her sayfada iki sütün halinde hazırlanmıştır. Kitabın 25x31 ölçülerinde hazırlanmış olması gravür, harita, plan ve fotoğrafların okuyucular tarafindan daha kolay incelenmesine yardımcı olmaktadır. Kaliteli kapak, renkli iç baskı ve kuşe kağıtla hazırlanmasından dolayı prestij kitap kategorisindedir.

Eserin giriş bölümü “Osijek: Mursa, Eszek, Ösek, Esek, Ossech, Esseck, Osik" başlığıyla Andrija Mutnjaković tarafindan kaleme alınmıştır. Eserin bu bölümünde ilk olarak şehrin isminin (Osijek) kökeni ve ne anlama geldiği hakkında bilgiler sunulmuştur. Bu bölümde şehrin antik dönemden itibaren tarihi hakkında çeşitli kaynaklarla desteklenerek bilgiler yer almaktadır. Romalılar döneminde Mursa adını taşıyan şehir, daha sonra jeostratejik konumundan ötürü Osmanlılar tarafindan önemli görülmüş ve uzun yıllar Osmanlı idaresi altında kalmıştır. Bu önemine binaen 1566 yllında Kanuni Sultan Süleyman tarafindan Osijek'te sekiz kilometre uzunlukta ahşap bir köprü yapılmıştır. Tamamlanan bu köprünün, dönemin çok önünde eşsiz özelliklere sahip olması gezginler ve devlet adamları tarafından Dünyanın sekizinci harikası olarak nitelendirilmesini ve Avrupa halklarına tanıtımı yapılmasını sağlamıştır.

Eserin birinci bölümü "The Great Bridge in Osijek: Historical Eyewitnessing" başlğ̆ıyla Milan Pelc tarafindan hazırlanmışır. Bu bölümde sunulan tasvirlerle 17. yüzyıldan 18. yüzyılın sonlarına kadarki döneme ait tanıklıklar paylaşılmışır. Köprüye ve şehre dair yazılı ve görsel malzemelerle zenginleştirilmiş bu bölüm özellikle batılı gezginlerin penceresinden Osijek'in algılanışını bizlere anlatmaktadır. Düşman toprağından geçerken saldırıya uğramak ya da casusluk ithamıyla idam 
edilme riski taşıyan batılılar, genellikle Osijek’i Osmanlı savaşlarıyla ilintili olarak tasvir etmişlerdir. Görsel çalışmalar casus ya da muhbirlerin raporlarına dayandıklarından ötürü, Osmanlıların stratejik/askeri öneme sahip yapılarına odaklanmışlardır. Öte yandan eldeki tek İslami betimleme Evliya Çelebi'nin Seyahatname'sinde yer almaktadır. Seyahatname'nin sayfalarında Osijek Köprüsünün ticari işlevini ve köprü trafiğini daha detaylı bir şekilde okumak mümkün olmuştur. Sunulan birçok kanıta rağmen, bu bölümün sonunda yazar yazılı ve görsel delillerin tarihi hakikati aktarmaya yeterli olmadı̆̆ını vurgulamıştır.

Eserin ikinci bölümü "Cisr-i Kebir-i Ösek" başlığıyla Nenad Moačanin tarafından kaleme alınmıştır. Bu bölümde Osmanlılardan kalan kayıtlarda köprüyle ilişkili birçok bilgi bulmanın mümkün olduğu; ancak, doğrudan köprüyü anlatan kaynağın çok az olduğu belirtilmiştir. Araştırmacı birçok tasvir ve kaynağa dayalı olarak köprünün kesin olarak Kanuni Sultan Süleyman'1n Zigetvar Seferi'ne atfetmenin zor olduğunu belirtmiştir. Öte taraftan Evliya Çelebi'nin Seyahatname'sinden alıntılarla da güçlendirilen araştırmanın bu bölümünde, Evliya'dan naklen bölgede Osmanlılardan önce de bir köprünün var olduğuna dair bilgiler paylaşılmıştır. Ayrıca köprünün ekonomik fonksiyonunun da değerlendirildiği araştırmada, bölgede ticari faaliyetlerin şekillenmesindeki rolü belirtilmiştir. Araştırmac1, köprünün Osmanlı idaresi altındaki nihai biçimine 15911606 arasında gerçekleşen Osmanl1-Avusturya Savaşları sonrasında ulaştığını öne sürmüştür.

Eserin üçüncü bölümü "Archaeological Research in Darda, The Suleiman Bridge Site” başlığıyla Mladen Pešić tarafindan hazırlanmıştır. Bu bölümde önceki iki bölümden farklı olarak tarihi yazılı ve görsel dokümantasyona değil, arkeolojik çalışmalar sonucu gün yüzüne çıkarılan mimari kalıntılara yer verilmiştir. 2008 yılında Darda nehrinin temizliği çalışması esnasında bulunan bazı kalıntılardan yola çıkılarak Hirvatistan Koruma Enstitüsü tarafindan bölgede 2009 ve 2011 yıllarında kurtarma çalışmaları yapılmıştır. Bölümün yazarı Pešić, bu bölümde ele alınan malzemeyi kurtaran sualtı arkeolojisi ekibinin üyesidir. Bu iki arkeolojik çalışmada bulunan 150'den fazla kalıntının analizi sonucunda köprü hakkında çok önemli bilgiler elde edilirken, köprünün tarihi önemi göz önüne alındığında hala elimizde çok az veri bulunduğu söylenebilir. Tatbik edilen radyo-karbon tarihlemesinin sonucunda, ahşap kalıntıların 1562'den önce kesilen ağaçlardan elde edildiğini ortaya koyan önemli bilgilere ulaşılmıştır. Bu durum köprünün inşasından birkaç yıl önce hazırlıklar yapıldığını ortaya koymaktadır. Araştırmacıya göre, arkeolojik çalışmaların devam etmesi, köprünün yakınında bulunan Esterházy Kalesi'nin restorasyonunda ulaşılacak verilerin de yardımıyla gelecekte köprüye dair daha güvenilir verilere ulaşmayı sağlayacaktır.

Eserin dördüncü bölümü "A Spatial and Historical Study of the Suleiman Bridge in Osijek" başlığıyla Ratko Vučetić ve Ivana Haničar Buljan tarafindan kaleme alınmıştır. Bu bölüme yazarlar, Osijek şehrinin Orta Çă̆'dan modern döneme kadar ifade ettiği önemi özetleyerek başlamaktadır. Bu bölüm, Avrupa'da yapılmış diğer 
köprüler ve köprülerin insan yaşamındaki yeriyle birlikte ele alınmıştır. Çalışmanın en hacimli kısmı, kitabin ana hedefine uygun olarak Osijek'te Osmanlilar tarafindan inşa edilen köprü olmuştur. Osmanlılar tarafindan ilk defa 1526'da geçici olarak duba köprü şeklinde inşa edilen yapı, 1566 ylında kalıı hale getirilmiştir. Araştırmacılara göre, Osmanlı Balkanlarında askeri istihbarat sisteminin bir ayağı olan bu köprü, Belgrad ve Budin şehirlerini de kapsayan köprüler dizisinin önemli bir parçasıdır. Köprü, Sokollu Mehmet Paşa döneminde artan ekonomik öneminden dolayı yeniden inşa edilmiş; boyutları, biçimi ve ifade ettiği önemden ötürü döneminin sıkça tasvir edilen meşhur köprülerinden birisi olmuştur.

Bölümün yazarları, Hırvat Bağımsızlık Savaşı (1991-1995) sırasında bölge mayınlanmış olduğu için saha araştırması yapmanın riskler taşıdığını belirtmiştir. Bunun yerine tarihi harita rektifikasyonu yapmış ve Viyana, Budapeşte ve İstanbul arşivlerinden malzeme toplamışlardır. Bu bölümün sonunda yazarlar köprü hakkında gelecekte yapılabilecek araştırmalar ve koruma-saklama faaliyetleri için çeşitli öneriler sunmuştur.

Kitab1 genel bağlamda değerlendirecek olursak, metnin iki dilde hazırlanmış olması okurlar için büyük kolaylık sağlamaktadır. Ancak, eserin sonunda dizin bulunmaması önemli bir eksikliktir. Bu eserin Türkçeye çevrilmesi ülkemizdeki Osmanlı tarihi araştırmaları için büyük bir kazanım olacaktır. Osijek'in Osmanlı dönemini ele alan literatürdeki en kapsamlı araştırma olarak ifade edilebilecek bu eserin hazırlanmasında Hırvat ve Türk paydaşların birlikte yer alması, gelecekte yapılabilecek araştırmalar için örnek bir proje niteliği kazanmasını sağlamıştır.

\section{Özgür Polat*}

* Arş. Gör., İzmir Kâtip Celebi Üniversitesi, Sosyal ve Beşerî Bilimler Fakültesi, Bilgi ve Belge Yönetimi Bölümü, 35620, Balatçık, Çiğli-İzmir/Türkiye, ozgur.polat@ikc.edu.tr, Orcid ID: 0000-0003-3993-4815 